\title{
Microbial community structure and biomass of a mine soil with different organic and inorganic treatments and native plants
}

\author{
Rosario Basanta ${ }^{1,2^{*}}$, Amarílis de Varennes ${ }^{1}$, Monserrat Díaz-Raviña ${ }^{2}$
}

${ }^{1}$ Instituto Superior de Agronomia, ULisbon, Tapada da Ajuda, 1349-017 Lisboa, Portugal. ${ }^{2}$ Departamento de Bioquímica del Suelo, Instituto de Investigaciones Agrobiológicas de Galicia (IIAG-CSIC), Apartado 122, Avda Vigo s/n, 15780, Santiago de Compostela, Spain. *Corresponding author: rosariobasan@gmail.com

\begin{abstract}
Heavy metals far in excess of trace amounts that are required for healthy plant growth, cause harmful effects on soil microorganisms; however, studies concerning the characterization of microbial communities in mine soils are scarce. The present study is the first attempt to characterize, by means of the analysis of phospholipid fatty acid (PLFA) patterns, soil microbial community composition from a contaminated mine soil ( $\mathrm{Pb}$, As) subjected to different remediation technologies. A pot experiment was performed with a soil from the São Domingos mine (South of Portugal) with or without native herbaceous plants combined with the following soil treatments: control; inorganic fertilizer (NPK); inorganic fertilizer plus polyacrylate polymer; inorganic fertilizer plus organic amendment (compost); inorganic fertilizer plus both amendments (compost, polymer). The measurements of PLFA patterns were made on soil samples collected 5 months after the application of remediation treatments. The total microbial biomass and the biomass of specific groups increased notably after soil treatments, particularly those including organic amendments, and were significantly higher in presence of native plants than in the corresponding bare soils. The data also indicated that a plant cover rather than organic and inorganic treatments played the dominant role in determining the composition of the microbial community. An influence of different soil treatments on microbial composition was also observed; the effect of organic amendment being more pronounced than that of the remaining treatments. The results clearly showed the efficacy of a vegetation cover (native plants) combined with the use of organic amendment in the reclamation of this degraded mine soil.
\end{abstract}

Keywords: Phytoremediation, inorganic fertilizer, compost, polymer, PLFA analysis 


\section{Introduction}

Nowadays, in situ remediation strategies for metal/ metalloid contaminated historical mining sites are focused on the use of amendments and/or metal-tolerant plants (some of them non-indigenous) and their associated microorganisms to reduce heavy metals mobility and bioavailability. These are promising alternative technologies to traditional options of excavations and ex situ treatment, offering an advantage of being non-invasive and low cost. The purpose of revegetation is to stabilize the site, by providing a cover crop that will prevent dispersion of metalcontaminated particles by water and wind erosion and reduce metal mobility by rhizosphere-induced adsorption and precipitation processes (Alvarenga et al., 2008). However, plant growth is very limited in mine contaminated soils (high levels of metals and metalloids, soil acidity, low $\mathrm{C}$ and nutrients availability) and soil amendments such as lime, organic residues and industrial products such as zeolites and insoluble polyacrylate polymers promote the establishment of a vegetation cover by providing essential nutrients for plant growth, raising the $\mathrm{pH}$, and chelating toxic metals (Alvarenga et al., 2008; 2014; Guiwei et al., 2008; de Varennes et al., 2010; Pinto et al., 2015).

Most studies concerning the rehabilitation of polluted soils in situ have focused on the effects of different treatment on bioavailability of trace elements and plant growth (Alvarenga et al., 2008; PérezLópez et al., 2008), but interventions at one level inherently affect the restoration attributes at other levels (Kardold and Wardle, 2010). During decades, links between above-ground changes and belowground activities carried out by soil microorganisms were often ignored, although they are determinant of ecosystem resilience and functional efficiency, and they can assist restoration ecology (Kardold and
Wardle, 2010). Thus, since soil amendments and plant growth may induce shifts in the soil microbial community (Grayston et al., 1998; Kourtev et al., 2003; Pérez de Mora et al., 2006; Carrasco et al., 2010), the microbial characterization of contaminated soils should be considered in the remediation studies.

During the last decade some investigations showing changes in microbial biomass and activity in mine stabilized soils have been published (Pérez de Mora et al., 2006; Clemente et al., 2007; Alvarenga et al., 2008; de Varennes et al., 2010). Nevertheless, due to drawbacks of the traditional culture dependent methods, information on how soil microbial community composition will be altered by these remediation techniques is still scarce. The analysis of the phospholipid fatty acids (PLFAs) makes possible to examine broad scale patterns in microbial community structure (Frostegård et al., 1993a) and generally, after the application of multivariate statistical analyses, whole community fatty acids profiles indicate which communities are similar or different. Thus, the PLFA technique has been used to compare microbial communities during altered environmental conditions under wide ranges of soil types, management practices, climatic origins and different perturbations (Frostegård et al., 1993a,b; Barreiro et al., 2010; 2015; Mahía et al., 2011; FernándezCalviño et al., 2012; González-Gómez et al., 2013; Muhammad et al., 2016; Moreno et al., 2017). Nowadays, PLFA has become a widespread method to characterize soil microorganisms because it is a rapid and inexpensive way of assaying the biomass and composition of microbial communities (Frostegård et al., 2011).

Metals and metalloids originating from leaching of sulphide-rich abandoned mines are a very important 
source of environmental pollution both in soils and water. The abandoned pyrite mine of São Domingos, Portugal, is still an acid mine drainage generator and a source for trace elements pollution, and hence a threat to the ecologic equilibrium. The environmental risk concerning mining wastes it is wellknown (Pratas et al., 2005; Pérez-López et al., 2008; Alvarenga et al., 2012); however, although a wide area of land became contaminated with trace elements and only supports sparse vegetation, no efforts were made for an environmental recovery of the mining site since the ceasing of the mine activity in 1966. Information about plant communities that are growing on metal-contaminated soils is essential to determine their application for mine stabilisation/remediation and biogeochemical exploration. In these abandoned mines of Portugal several plant species have been recognized as tolerant to the mining environment by accumulating or excluding toxic metals (Pratas et al., 2005; Abreu et al., 2008; Nabais et al., 2008; Pinto et al., 2015) and could be used in ecological restoration projects. Other approaches to remediate these acidic poor soils contaminated with trace metals are to add soil amendments for improving soil fertility and hence plant growth. To this respect it has been shown that soil amendments, including materials from farming and industrial sources (Alvarenga et al., 2008; Guiwei et al., 2008), could be a good ecological alternative to recycle these residues and to reclaim these degraded soils. However, additional research is still needed if technologies based on the combined action of plants and the microbial communities they support within the rhizosphere are adopted in large-scale remediation actions (Nabais et al., 2008).

Previous studies have shown that the combined use of native plants (Briza maxima, Chaetopogon fasciculatus and Spergularia purpurea), inorganic fertilizer (NPK) and soil amendments such as organic wastes (municipal solid waste compost) and polyacrylate polymer, stimulated plant growth and improved the quality of the mine soil. The latter was indicated by greater levels of overall metabolic activity (soil respiration and dehydrogenease) and several enzyme activities involved in the soil cycles of $\mathrm{N}, \mathrm{P}$ and $\mathrm{C}$ (urease, protease, phosphatase, $\beta$-glucosidase and cellulose) found by de Varennes et al., 2010). Hydrophylic polymers or "superabsorbent polymers" were incorporated into soils and substrates when an increase in the water holding capacity is desirable. In free solution, the ionic species of several metals are rapidly trapped within and insoluble polyacrilate polymer and not released upon subsequent incubation of the particles with water. This capacity to chelate metal cations suggests that these polymers could be used for in situ remediation of metal contaminated soils. These insoluble polymers enhance plant growth by increasing water-holding capacity, supplying the cation present and decreasing the bioavailability of same trace elements (Guiwei et al., 2008). Hence, these remediation measures were efficient as soil reclamation techniques. Often, remediation studies on heavy metal contaminated soils have focused on the monitoring of bio-available or total metal content and information about the microbial communities is scarce despite it is well-know that can provide important information when evaluating soil remediation since microbial changes can also affect soil functionality, thereby influencing nutrient turnover and the restoration process of the degraded contaminated soil. However, despite its interest, information on both biomass and composition of soil microbial communities is not available. The aim of this study was to determine whether the microbial activity changes detected in São Domingos mine soil following different rehabilitation tecniques (de Varennes et al., 2010) were accompanied by changes in the microbial biomass and community structure. 


\section{Material and Methods}

\subsection{Pot experiment}

The soil used in the experiment was collected from the former São Domingos mine $\left(37^{\circ} 40^{\prime} \mathrm{N}, 7^{\circ} 30^{\prime} \mathrm{W}\right)$, a pyrite mine located in the Iberian Pyrite Belt near the border with Spain. Modern extraction of $\mathrm{Cu}$ began in the $19^{\text {th }}$ century and took place until 1966 when the mine was close and the mine tailings were left without any treatment or containment causing the soil contamination with trace metals. The soil (fraction < $2 \mathrm{~mm})$ had a sandy loam texture, was highly acidic ( $\mathrm{pH}$ in water 4.1), poor in organic matter (1.1 g organic C $\mathrm{kg}^{-1}$ ) and plant nutrients (3.36 mg inorganic $\mathrm{N} \mathrm{kg}^{-1}, 0.44$ $\mathrm{g}$ total $\mathrm{P} \mathrm{kg}^{-1}$ and $3.1 \mathrm{~g}$ total $\left.\mathrm{K} \mathrm{kg}^{-1}\right)$, and with large total contents of $\mathrm{Pb}\left(6160 \mathrm{mg} \mathrm{kg}^{-1}\right)$ and As $(2730 \mathrm{mg}$ $\left.\mathrm{kg}^{-1}\right)$. The pot experiment was performed with the mine soil without plants (bare soil) or with a mixture of native herbaceous plants (planted soil, Briza maxima L., Chaetopogon fasciculatus (Link) Hayek and Spergularia purpurea (Persoon) G. Don fil.) combined with the following treatments (4 replicates per treatments,
$4 \mathrm{~kg}$ soil per pot): control (C); inorganic fertilizer (I; $200 \mathrm{mg} \mathrm{N}, 125 \mathrm{mg} \mathrm{P}, 420 \mathrm{mg} \mathrm{K}$ and $25 \mathrm{mg} \mathrm{Mg} \mathrm{kg}^{-1}$ soil.); inorganic fertilizer plus polyacrylate polymer, half with $\mathrm{K}^{+}$as counter ion and half $\mathrm{NH}_{4}^{+}(\mathrm{P} ; 0.4 \%$ of polyacrylate polymer, $125 \mathrm{mg} \mathrm{P}, 25 \mathrm{mg} \mathrm{Mg} \mathrm{kg}{ }^{-1}$ soil); inorganic fertilizer plus organic amendment (O; $200 \mathrm{mg} \mathrm{N}, 125 \mathrm{mg} \mathrm{P}, 420 \mathrm{mg} \mathrm{K}, 25 \mathrm{mg} \mathrm{Mg}$ and $15 \mathrm{~g}$ of municipal solid waste compost $\mathrm{kg}^{-1}$ soil); fertilizer plus both amendments, polymer and compost (PO; $0.4 \%$ of polyacrylate polymer, $15 \mathrm{~g}$ of compost $\mathrm{kg}^{-1}$ soil, $125 \mathrm{mg} \mathrm{P}, 25 \mathrm{mg} \mathrm{Mg}$ ). The properties of the compost are the following: $\mathrm{pH}, 8 ; 329 \mathrm{~g} \mathrm{C} \mathrm{kg}^{-1}$; $7.99 \mathrm{~g} \mathrm{P} \mathrm{kg}^{-1} ; 16 \mathrm{~g} \mathrm{~K} \mathrm{~kg}^{-1} ; 273 \mathrm{mg} \mathrm{Cu} \mathrm{kg}{ }^{-1} ; 560 \mathrm{mg}$ $\mathrm{Zn} \mathrm{kg}^{-1} ; 307 \mathrm{mg} \mathrm{Pb} \mathrm{kg}^{-1} ; 15 \mathrm{mg} \mathrm{As} \mathrm{kg}{ }^{-1}$. It is important to note than $\mathrm{Pb}$ and $\mathrm{As}$ were considerably lower than those in the mine soils. A detailed description of soil, rehabilitation treatments and experimental design is given by de Varennes et al. (2010). The measurements of PLFA patterns were made on soil samples collected 5 months after the application of treatments. The plant biomass accumulation and soil $\mathrm{pH}$ of the mine soil with different treatments are indicated in Table 1.

Table 1. Phytomass yields $\left(\mathrm{g} \mathrm{pot}^{-1}\right)$ and soil $\mathrm{pH}$ of the mine soil with different rehabilitation treatments after 5 months (mean values of four pot replicates). Treatments: C, control; I, inorganic fertilizer; P, inorganic fertilizer plus polymer; $\mathrm{O}$, inorganic fertilizer plus compost; $\mathrm{PO}$, inorganic fertilizer plus both amendments (polymer, compost). For each parameter different letters indicate significant differences at the $\mathrm{P}<0.05$ level.

\begin{tabular}{llccccc}
\hline & & \multicolumn{4}{c}{ Soil treatment } \\
\cline { 3 - 7 } & & $\mathrm{C}$ & $\mathrm{I}$ & $\mathrm{P}$ & $\mathrm{O}$ & OP \\
\hline Phytomass yield** & Planted soil & $0.90 \mathrm{a}$ & $20.83 \mathrm{~b}$ & $34.92 \mathrm{c}$ & $35.30 \mathrm{c}$ & $46.61 \mathrm{~d}$ \\
$\mathrm{pH}_{\text {water }}$ & Bare soil & $4.54 \mathrm{~b}$ & $4.50 \mathrm{~b}$ & $4.69 \mathrm{c}$ & $6.28 \mathrm{f}$ & $5.97 \mathrm{e}$ \\
& Planted soil & $4.51 \mathrm{~b}$ & $3.92 \mathrm{a}$ & $4.98 \mathrm{~d}$ & $6.93 \mathrm{~h}$ & $6.66 \mathrm{~g}$ \\
\hline
\end{tabular}

*Data taken from Varennes et al. (2010) 


\subsection{Microbial community structure}

The microbial community structure was determined by the PLFA analysis using the procedure and nomenclature described by Frostegård et al. (1993a). Briefly, the lipids were extracted from the soil with a chloroform:methanol:citrate buffer mixture (1:2:0.8 $\mathrm{v} / \mathrm{v} / \mathrm{v}$ ) and separated into neutral lipids, glycolipids and phospholipids using a pre-packed silica column. The phospholipids were subjected to a mild alkaline methanolysis and the fatty acid methyl esters were identified by gas chromatography (flame ionization detector) by the relative retention times of the fatty acids, using methyl nondecanoate (19:0) as internal standard. Fatty acids (PLFA) are designated in terms of the total number of carbon atoms: number of double bounds, followed by the position of the double bound from the methyl end of the molecule. Cis and trans configurations are indicated by $\mathrm{c}$ and $\mathrm{t}$, respectively. The prefixes a and i indicate anteiso- and iso-branching; br indicates unknown methyl branching position, $10 \mathrm{Me}$ indicates a methyl group on the tenth carbon atom from the carboxyl end of the molecule; and cy refers to cyclopropane fatty acids. The total microbial biomass (TotPLFAs) was estimated as the sum of all the extracted PLFAs. The sum of the PLFAs considered to be predominantly of bacterial origin was used as an index of the bacterial biomass (BactPLFAs), the quantity of the PLFA 18:2 $\omega$ 6,9 was used as an indicator of the fungal biomass (FungPLFA), the PLFAs i14:0, a15:0, i16:0 and 10Me18:0 as indicators of gram-positive $\left(\mathrm{G}^{+}\right)$bacteria, and the PLFAs cy17:0,

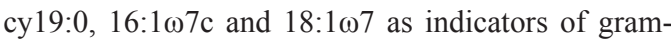
negative ( $\left.\mathrm{G}^{-}\right)$bacteria (Díaz-Raviña et al. 2006). The biomass data were analyzed by ANOVA 2 to determine the percentage of the data variation attributable to the factors revegetation $(\mathrm{V})$ and soil treatment $(\mathrm{T})$. To compare soil treatments, biomass data were also analyzed by ANOVA 1 followed by Tukey's test to differentiate between the means. Concentration of all the individual PLFAs data, expressed as mole percentage and logarithmically transformed, was subjected to principal component analysis (PCA) to elucidate the main differences in the PLFA patterns. Relationships between soil and plant variables were obtained using Pearson correlations. Calculations of the basic descriptive statistics, correlation and ANOVAs were performed using SPSS v.15.0 for Windows.

\section{Results}

The microbial biomass, estimated as tot PLFAs, ranged from 1.8 to $7.7 \mathrm{nmol} \mathrm{g}^{-1}$ in the bare soils, and from 4.0 to $20.7 \mathrm{nmol} \mathrm{g}^{-1}$ in the planted soils (Figure 1). The bacteria and fungi comprised 29$49 \mathrm{~mol} \%$ and $17-27 \mathrm{~mol} \%$, respectively, of the total amount of PLFAs. The total microbial biomass and the biomass of specific groups were quite similar in bare and planted untreated soils but increased notably after soil treatments, higher biomass values being observed in presence of native plants with organic amendments. For both bare and planted soils, the soil receiving the compost amendment $(\mathrm{O}, \mathrm{PO})$ showed significantly higher values than those with inorganic fertilizer (I) or polymer (P) treatments. The abundance of the specific microbial groups differed significantly between bare soil and the corresponding planted soil, the bare soil samples showing lower biomass values and a higher Fung PLFA/bacPLFA index ratio (Figure 1). In general, total microbial biomass and biomass of specific groups of soil microorganisms (bacteria, fungi) here determined were positively and significantly related with yield production, soil $\mathrm{pH}$, and several biochemical properties previously determined by de Varennes et al., 2010) in the same pot experiment and related with the activity of soil microorganisms, the only exceptions being urease and protease activities (Table 2). 


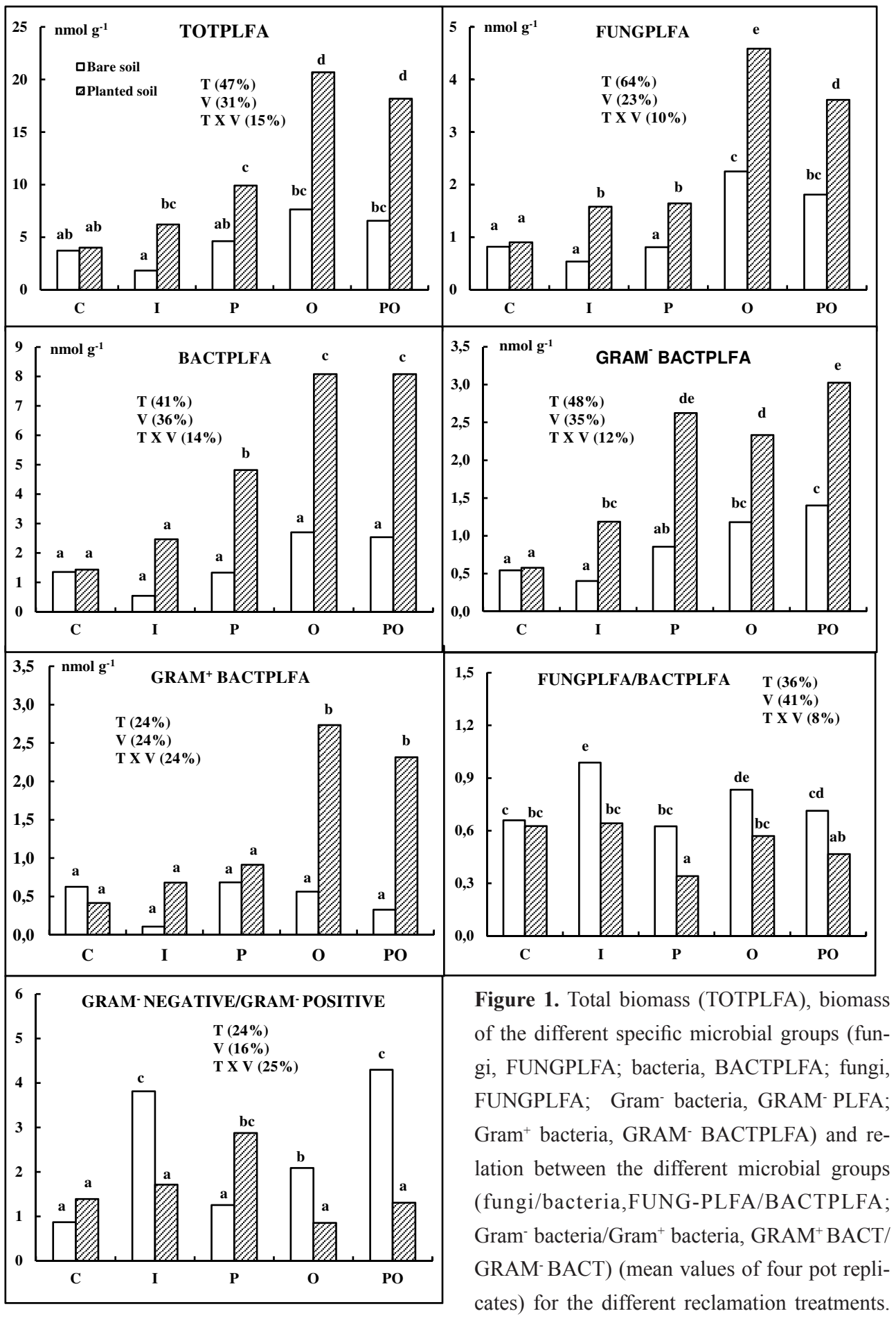


Treatments: C, control; I, inorganic fertilizer; $\mathrm{P}$, inorganic fertilizer plus polymer; $\mathrm{O}$, inorganic fertilizer plus compost; PO, inorganic fertilizer plus both amendments (polymer, compost). Different letters indicate significant differences at the $\mathrm{P}<0.05$ level.
For each analyzed parameter ANOVA 2 (revegetation, V; soil treatment, T; V X T interaction) were performed, but only proportion of variance explained by significant factors $(\mathrm{P}<0.05$ level $)$ are indicated.

Table 2. Correlation coefficient values between microbial biomass estimated by means of phospholipid fatty acid analysis (total microbial biomass and biomass of specific microbial groups) and soil properties and yield production. * $\mathrm{P}<0.05 ; * * \mathrm{P}<0.01 ; * * * \mathrm{P}<0.001$.

\begin{tabular}{lccccc}
\hline Variable & Total PLFA & Fungal PLFA & Bacterial PLFA & $\mathrm{G}^{-}$bacteria & $\mathrm{G}^{+}$bacteria \\
\hline Respiration $^{\mathrm{a}}$ & $0.838^{* *}$ & $0.787 * *$ & $0.875 * *$ & $0.912 * *$ & $0.723 *$ \\
Dehydrogenase $^{\mathrm{a}}$ & $0.881^{* *}$ & $0.930^{* *}$ & $0.835 * *$ & $0.688 *$ & 0.139 \\
Cellulase $^{\mathrm{a}}$ & $0.809 * *$ & $0.722 * *$ & $0.851 * *$ & $0.920 * *$ & $0.714 *$ \\
Glucosidase $^{*}$ & $0.835^{* *}$ & $0.742 *$ & $0.899 * *$ & $0.979 * *$ & $0.749 *$ \\
Protease $^{\mathrm{a}}$ & 0.352 & 0.406 & 0.308 & -0.293 & 0.354 \\
Urease $^{\mathrm{a}}$ & -0.366 & -0.356 & -0.388 & -0.378 & -0.265 \\
Phosphatase $^{\mathrm{a}}$ & $0.720 *$ & 0.571 & $0.809 * *$ & $0.953 * *$ & $0.652 *$ \\
pH $^{\mathrm{a}}$ & $0.807 * *$ & $0.864 * *$ & $0.768 * *$ & 0.595 & 0.313 \\
Yield production $^{\mathrm{a}}$ & $0.851^{* *}$ & $0.740 *$ & $0.906 * *$ & $0.959 * *$ & $0.658 *$ \\
\hline
\end{tabular}

${ }^{\mathrm{a}}$ Data taken from Varennes et al. (2010)

The results of ANOVA showed a significant effect of soil treatments and the presence of plants on the PLFA concentrations, the factors not being independent as indicated by the significant effect of the interaction between them (Figure 1). Variation in totPLFA was largely explained by the soil treatment $(47 \%)$ but also by the presence of plants $(31 \%)$ and the soil treatment-vegetation interaction (15\%). A similar influence of these factors was observed for specific microbial groups, soil treatment explained between $24 \%\left(\mathrm{Gram}^{+}\right.$bacteria) to $64 \%$ (fungi) of the variance, the presence of plants accounted for a $23-36 \%$ and the interaction $8-24 \%$. Likewise, a significant effect of soil treatment, vegetation and the interaction between these factors on Fung/Bact PLFA and $\mathrm{Gram}^{+} / \mathrm{Gram}^{-}$ ratios was detected.
Score ( \pm SE of four pot replicates) and loading plots from PCA performed on the whole PLFAs data set (soils samples with and without vegetation) are showed in Figure 2. The PCA analysis indicated that the main differences in the PLFA pattern were due to the vegetation cover implantation. The first component (PC1), differentiating between bare soil and planted soils, explained $27 \%$ of the variation, while the second component (PC2) mainly differentiated between treatments with compost and polymer ( $\mathrm{O}$ and $\mathrm{P})$ and the others, explaining $23 \%$ of the variation. The planted soils (with positive values along PC1) were characterized by relatively high concentrations of branched saturated PLFAs i15:0, i16:0, a15:0 and monounsaturated PLFAs 16:1 $\omega 9,16: 1 \omega 5,17: 1 \omega 8$ (Figure 2), whereas the bare soils (with negative values along PC1) showed 
relatively high concentrations of the PLFAs cy19:0, 18:0 and 10Me17:0. The soils receiving compost and polymer (positive values along PC2) were characterized by high concentrations of monounsaturated 19:1a,
18:1 $\omega 7,18: 1 \omega 9$ and branched saturated 17:0 and 20:0, and the soils receiving only inorganic fertilizer by high concentrations of the 10Me16a, 10Me17:0 and br18:0.
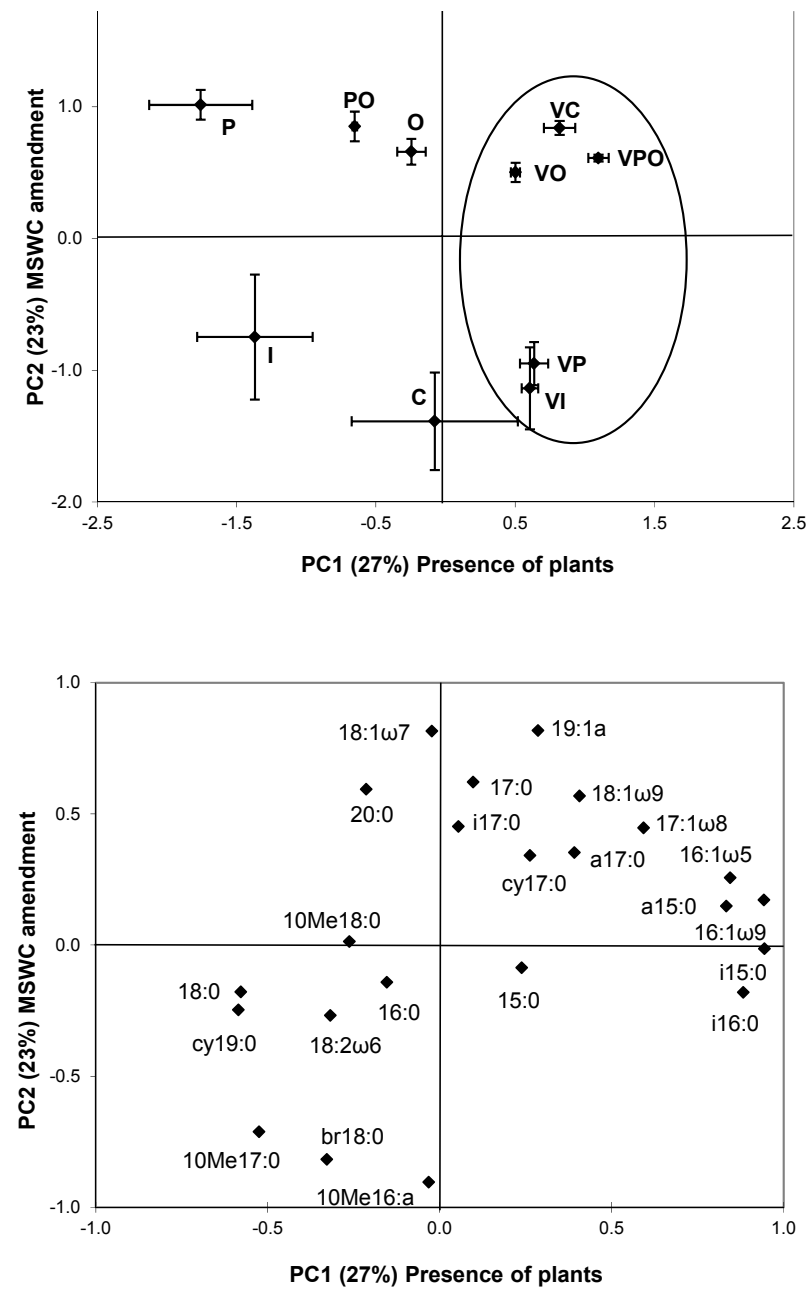

Figure 2. Score ( \pm SE of four replicates) and loading plots from PCA performed on the PLFAs of the soils with vegetation $(\mathrm{V})$ and the bare soil samples. Treatments: $\mathrm{C}$, control; I, inorganic fertilizer; $\mathrm{P}$, inorganic fertilizer plus polymer; $\mathrm{O}$, inorganic fertilizer plus compost; $\mathrm{PO}$, inorganic fertilizer plus both amendment (polymer, compost); VC, planted soil; VI planted soil with inorganic fertilizer; VP planted soil with polymer fertilizer; VO planted soil with compost fertilizer; VPO planted soils with both amendments (polymer, compost). 


\section{Discussion}

The mine soil is acidic and very poor in $\mathrm{C}$ and nutrients and total $\mathrm{Pb}$ and $\mathrm{As}$ concentrations were much greater than the maximum allowed limits for healthy plant growth (Dudka and Miller, 1999). Under this very poor and metal stressed soil environment where, in addition, low soil $\mathrm{pH}$ favoured $\mathrm{Pb}$ availability, plant growth and microbial activity of soil microorganisms are extremely reduced. In consequence, plant growth and soil functioning is expected to be notably stimulated by the application of soil amendments increasing $\mathrm{C}$ and nutrient availability and reducing metal availability. At the end of the greenhouse experiment the phytomass production in control soil was only $0.9 \mathrm{~g} \mathrm{pot}^{-1}$ whereas the crop yield ranged from 20.8 to $46.6 \mathrm{~g} \mathrm{pot}^{-1}$ in the mine soils with different treatments (Table 1). In all cases the treatment increased the phytomass production by a factor of 23-52, compared to the control, the increase being particularly striking for soil receiving both polyacrylate polymer and compost amendments. It should be noticed that under field conditions this degraded soil supports only sparse vegetation, therefore the establishment of a plant cover is essential to decrease both soil erosion and water contamination with acid drainage containing trace elements. These results clearly showed the efficacy of rehabilitation strategies for this mine polluted soil, which is also in accordance with soil quality reflected by some biochemical properties determined in the same greenhouse experiment (de Varennes et al. 2010).

This mine untreated soil exhibited low total microbial biomass values with a high proportion of fungi, which is consistent with the fact that fungi rather than bacteria are favoured in polluted environments due to their greater tolerance to heavy metals (Bååth, 1989; Frostegård et al., 1993b). Changes in microbial biomass values were detected 5 months after the application of remediation treatments, but a different response was observed depending on treatment considered. Revegetation had a significant effect on the biomass values; thus, the planted soils showed values 2-4.5 times higher than those in the corresponding bare soils. Likewise, a positive correlation between biomass values and vegetation cover was observed (Table 2), which most likely was due to the increased availability of carbon and energy in the rhizosphere (Wardle, 1992). These data clearly showed the interdependence between above-ground changes and below-ground processes carried out by soil microorganisms (Kardold and Wardle, 2010) and emphasized the importance of monitoring soil microbial parameters in remediation studies. It should be noticed, however, that plant cover effect on microbial biomass did not seem to be as influential as that of the soil treatment. Variation in biomass data was also explained by soil treatment, but a different effect was observed in presence and absence of plants. In bare soils, inorganic fertilizer and polymer treatments showed similar or even lower biomass values than control soils whereas in compost amendment alone or combined with polymer increased the biomass values about two times; this was also most likely due to increased input of carbon for the soil microorganisms. In planted soils all rehabilitation treatments showed a significant effect on biomass values, the magnitude of change induced by compost amendments (increase of 4-6 times) being much higher than that observed when inorganic fertilizer and polymer were added (increase of 2 times). The fact that the influence of soil treatment was more pronounced in planted soils than in bare soils clearly showed the benefits of combining a plant cover with soil treatments in the soil reclamation process. Relative biomass of fungi and bacteria also varied depending on presence of plants, the planted soils showing lower FungPLFA/BactPLFA ratios than bare soils due to the fact that in the rhizosphere bacteria rather than fungi are stimulated (Wardle 1992). $\mathrm{Gram}^{-1} \mathrm{G}^{+}$ratio 
was higher in planted untreated control and in planted soil with polyacrylate polymer (VC, VP) than in the bare untreated soil $(\mathrm{C}, \mathrm{P})$, which can be due to the increased dominance of G- bacteria under conditions of high substrate and nutrients availability found as consequence of the rhizosphere and the fertilizer addition influence (Söderberg et al., 2004). In contrast, amended planted soils (VI, VO, VPO) showed lower $\mathrm{Gram} / \mathrm{G}^{+}$ratio ratios than the corresponding bare soils, which can be partly explained by the nutrient immobilization by plants.

Significant positive relationship between microbial biomass (total PLFA, bact PLFA, fungal PLFA) and most microbial activity indices (soil respiration, dehydrogenase, cellulase, $\beta$-glucosidase and phosphatase) measured by de Varennes et al. (2010) were observed (Table 2), confirming the results of Pérez-de-Mora et al. (2006). Increased levels of overall microbial activity or specific enzyme activity do not necessarily have to coincide with an enhanced biomass; however, our results clearly showed that these measurements giving information on different aspects of soil microorganisms (size, activity) responded similarly to the reclamation treatments. In contrast, no significant positive correlations were found between microbial biomass and enzymes involved in the $\mathrm{N}$ cycle (protease and urease activities), which may result from the fact that these enzymes can also occur as free extracellular enzymes (Nannipieri et al., 2002). Our soils also exhibited significant positive correlation between microbial biomass and soil $\mathrm{pH}$, which is consistent with previous findings (Wardle, 1992; Díaz-Raviña et al., 1995). Other recent studies, however, showed that PLFA composition rather than total concentration of PLFA was affected by soil pH (FernándezCalviño et al., 2012).

The results showed that the PLFA pattern discriminated among different remediation measures and that the microbial community structure was mainly affected by the presence of plants and in a lesser extent by the soil treatments (Figure 2, organic- amendment). This is in accordance with previous studies showing significant changes in microbial community structure in response to either synthetic root exudates (Griffith et al., 1999) or specific physico-chemical and biological characteristics prevailing in the rhizosphere habitat (Söderberg et al., 2004; Pérez-de-Mora et al., 2006). It should be noticed that whereas in bare soil the microbial community of control soil was closer to that from inorganic fertilizer treatment than to that from the organic amendments, the opposite was true in planted soil indicating that somehow the development of a root system and organic amendment induced similar shifts in the microbial community structure. This clearly showed the benefits of the implantation of a vegetation cover in these degraded mine soils; however, since plant growth and associated biomass and activity of soil microorganisms are very reduced in untreated soil (Tables 1-2, Figure 1), the use of soil amendments is recommended in the restoration of these contaminated soils.

Different soil microbial communities were also observed depending on soil amendment (Figure 2). Nature of the amendment and therefore different accumulative effects of these compounds such as changes in the soil environment (soil properties and plant growth), can be responsible for the establishment of different microorganisms. The addition of organic materials not only should increase notably the organic matter content of this poor mine soil but also reduce the trace elements bioavailability through complexation processes (Alvarenga et al., 2008), which is crucial to soil quality and to the regulation of many soil functions; therefore, the use of organic amendments is recommended for reclamation of soils contaminated with heavy metals (Saffari et al., 2015). In the present study the addition of compost increased the $\mathrm{pH}$ around 1.7 units in bare soil and 2.5-3.0 units in planted soil, 
which can have important implications for nutrient availability, including trace elements present in soil $(\mathrm{Pb}, \mathrm{As})$. In fact, increasing soil $\mathrm{pH}$ is a common practice in acid soils affected by trace element pollution (Adriano, 2001), since most of these elements are less soluble at high $\mathrm{pH}$.

Differences in soil $\mathrm{pH}$ could also be responsible for the establishment of different microorganisms. Variations in soil PLFA pattern attributable to soil $\mathrm{pH}$ are reported in several studies showing an increase of 16:1 105 , as well as other monounsaturated PLFAs, with increasing $\mathrm{pH}$ and a decrease in some branched PLFAs, as well as cy 19:0, at high pH (Frostegård et al., 1993a; Fernández-Calviño et al., 2012). In our case the effect of $\mathrm{pH}$ on microbial composition seems evident since PCA analysis discriminated between soils with highest $\mathrm{pH}$ values such as those receiving compost amendment and the other soils and similar changes induced by $\mathrm{pH}$ were observed in some PLFAs; however, the fact that control planted soil ( $\mathrm{pH}$ of 4.5) was grouped together with soils receiving organic treatments $(\mathrm{pH}$ of 6-7) seems to indicate that other factors rather than soil $\mathrm{pH}$ are also important for determining the microbial composition of these mine soils contaminated with heavy metals. It should be noticed that although remediation measures modified microbial community structure it is extremely hard to discern the contribution of different soil properties since a combination of changes in soil environment ( $\mathrm{pH}$, metal toxicity, $\mathrm{C}$ availability, nutrients) are accounted for the microbial differences observed in the various reclamation treatments.

Changes in microbial composition due to inorganic fertilizer and polymer addition were also observed, this behaviour being attributed to the increased nutrient availability for the former treatment and to the $\mathrm{pH}$ changes (increase or decrease of 0.2-1.0 units) and the capacity to retain water and chelate trace elements for the later which in turn can influence soil microorganisms. This is also consistent with a previous studies showing a significant effect of a synthetic polymer (Firesorb, an acrylic-acrylamide copolymer) on both biomass and microbial composition applied at normal field dose as water additive to combat wildfire and to control prescribed fire in forests ecosystems (Díaz-Raviña et al., 2006; Barreiro et al., 2010).

\section{Conclusions}

Our results showed that changes in microbial activity detected in previous work after different rehabilitation treatments are accompanied by changes in microbial biomass and microbial community structure determined means of PLFA analyses. The implantation of a vegetation cover with native metal tolerant plants and soil treatments are important factors in determining the biomass and composition of microbial communities and hence in improving soil quality of these mine areas. Soil treatments (inorganic fertilizer, polymer and compost), particularly the organic material combined or not with polymer, can improve notably the reestablishment of soil microbial population and associated plant growth. In the present study, where a close link between different microbial aspects (biomass, activity and diversity) and associated plant growth was observed, the data comparison obtained for different soil treatments clearly showed that the best option for reclaiming this São Domingos mine soil is the implantation of a vegetation cover with the use of compost alone or combined with polymer. This shows the value of microbial parameters as a complementary promising tool to elucidate management effects that maybe not be apparent through traditional assessments of rehabilitation status such as above-ground (plant growth) or below-ground (soil physical and chemical properties) indicators. 


\section{Acknowledgements.}

This study was funded by the project PPTDC/ AMB/5758672994 from the Fundação para a Ciencia e a Tecnología (FCT). The authors wish to acknowledge Prof. Erland Bååth for his comments, which have led to the improvement of the original manuscript.

\section{References}

Abreu, M.M., Tavares, M.T., Batista, M.J. 2008. Potential use of Erica andevalensis and Erica australis in phytoremediation of sulphide mine environments: São Domingos. Portugal. Journal of Geochemical Exploration. 96, 210-222.

Adriano, D.C. 2001. Trace elements in terrestrial environments: biogeochemistry, bioavailability and risks of metals, Secons ed., Springer, New York.

Alvarenga, P., Gonçalves, A.P., Fernandes, R.M., de Varennes, A., Vallini, G., Duarte, E., Cunha-Queda, A.C. 2008. Evaluation of composts and liming materials in the phytostabilization of a mine soil using perennial ryegrass. Science of the Total Environment. 406, 43-56.

Alvarenga, P., Palma, P., de Varennes, A., ChunchaQueda, A.C. 2012. A contribution towards the risk assessments of soils from São Domingos (Portugal): chemical, microbial and ecotoxicological indicators. Environmental Pollution. 161, 50-56.

Bååth, E. 1989. Effects of heavy metals on microbial processes and populations (a review). Water, Air and Soil Pollution. 47, 335-379.

Barreiro, A., Fontúrbel., M.T., Lombao, A., Martín, A., Vega., J.A., Fernández, C., Carballas, T., DíazRaviña, M., 2015. Using phospholipid fatty acid and community level physiological profiling techniques to characterize soil microbial communities following an experimental fire and different stabilization treatments. Catena. 135, 419-429.

Barreiro, A., Martín, A., Carballas, T., Díaz-Raviña, M. 2010. Response of soil microbial communities to fire and fire-fighting chemicals. Science of the Total Environment. 407, 6172-6178.

Carrasco, L., Gattinger, A., Fließbach, A., Roldán, A., Scholoter, M., Caravaca, F. 2010. Estimation by PLFA of microbial community structure associated with the rhizosphere of Lygeum spartum and Piptatherum miliaceum growing in semiarid mine tailings. Microbial Ecology. 60, 265-271.

Clemente, R., de la Fuente, C., Moral, R., Bernal, M.P. 2007. Changes in microbial biomass parameters of a heavy metal-contaminated calcareous soil during a field remediation experiment. Journal of Environmental Quality. 36, 1137-1144.

de Varennes, A., Cunha-Queda, C., Guiwei. Q. 2010. Amendment of an acid mine soil with compost and polyacrylate polymers enhances enzymatic activities but may change the distribution of plant species. Water Air Soil Pollution. 208, 91-100.

Díaz-Raviña, M., Acea, A., Carballas, T. 1995. Seasonal changes in microbial biomass and nutirent flush in forest soils. Biology and Fertility of Soils. 19, 220-226.

Díaz-Raviña, M., Bååth. E., Martín. A., Carballas, T. 2006. Microbial community structure in forest soils treated with a fire retardant. Biology and Fertility of Soils. 42, 465-471.

Dudka S., Miller, W.P. 1999. Permissible concentrations of arsenic and lead in soils based on risk assessment. Water, Air Soil Pollution. 114, 127-132.

Fernández-Calviño, D., Arias-Estévez, M; DíazRaviña, M., Bååth, E. 2012. Assessing the effects of $\mathrm{Cu}$ and $\mathrm{pH}$ on microorganisms in highly acid vineyard soils. European Journal of Soil Science. $63,571-578$. 
Frostegård, Å., Bååth, E., Tunlid, A. 1993a. Shifts in the structure of soil microbial communities in limed forests as revealed by phospholipid fatty acid analysis. Soil Biology and Biochemistry. 25, 723-730.

Frostegård, Å., Tunlid, A., Bååth, E. 1993b. Phospholipid fatty acid composition, biomass and activity of microbial communities from two soil types experimentally exposed to different heavy metals. Applied and Environmental Microbiology. 95, 3605-3617.

Frostegård, Å., Tunlid, A., Bååth, E. 2011. Use and misuse of PLFA measurements in soils. Soil Biology and Biochemistry. 43, 1621-1625.

González-Gómez, M.J., Díaz-Raviña, M., Romero, E., Nogales, R. 2013. Recycling of environmentally problematic plant wastes generated from greenhouse tomato crops through vermicomposting. International Journal of Environmental Science and Technology. 10, 697-708.

Grayston, S., Wang, S., Campbell, C., Edwards, A. 1998. Selective influence of plant species on microbial diversity in the rhizosphere. Soil Biology and Biochemistry. 30, 369-378.

Griffith, B.S., Ritz, K., Ebblewhite, N., Dobson, G. 1999. Soil microbial community structure: effects of substrate loading rates. Soil Biology and Biochemistry. $31,145-153$.

Guiwei, Q., de Varennes, A., Cunha-Queda, C. 2008. Remediation of a mine soil with insoluble polyacrylate polymers enhances soil quality and plant growth. Soil Use and Management. 24, 350-356.

Kardold, P., Wardle, D.A. 2010. How understanding aboveground-belowground linkages can assist restoration ecology. Trends in Ecology and Evolution. 25, 670-679.
Kourtev, P.S., Ehrenfeld, J.G., Häggblom, M. 2003. Experimental analysis of the effect of exotic and native plant species on the structure and function of soil microbial communities. Soil Biology and Biochemistry. 35, 895-905

Mahía, J., González-Prieto, S.J., Martín, A., Bååth, E., Díaz-Raviña, M. 2011. Biochemical properties and microbial community structure of five different soils after atrazine addition. Biology and Fertility of Soils. 47, 577-589.

Moreno, J.L., Ondoño, S., Torres, I., Bastida, F. 2017. Compost, leonardite and zeolite impacts on soil microbial community under barley crops. Journal of Soil Science and Plant Nutrition. 17, 214-230.

Muhammed, W.P., Brookes, P.C., Wu, J. 2016. Addition impact of biochar from different feed stocks on microbial community and available concentrations of elements in a Psammaquent and a Plinthudult. Journal of Soil Science and Plant Nutrition. 16, 137-153.

Nabais, C., Gonçalves, C., Freitas, H. 2008. Phytoremediation in Portugal: Present and Future. In: Methods in Biotechnology Vol. 23: Phytoremediation: Methods and Reviews, N. Willey (Ed.), pp 405-421. Humana Press Inc, Totowa, NJ.

Nannipieri, P., Kandeler, E., Ruggiero, P. 2002. Enzyme activities and microbiological and biochemical processes in soil. In: R.G. Burns, R.P. Dick (Eds.), Enzymes in the Environment: Activity, ecology and applications. Marcel Dekker: New York. pp. 1-33

Pérez-de-Mora, A., Burgos, P., Madejón, E., Cabrera, F., Jaeckelb, P., Schloterb, M. 2006. Microbial community structure and function in a soil contaminated by heavy metals: effects of plant growth and different amendments. Soil Biology and Biochemistry. 38, 327-341. 
Pérez-López, R., Álvarez-Valero, A.M., Nieto, J.M., Sáez, R., Matos, J.X. 2008. Use of sequential extraction procedure for assessing the environmental impact at regional scale of the São Domingos Mine (Iberian Pyrite Belt). Applied Geochemistry. 23, 3452-3463.

Pinto, A.P., De Varennes, A., Fonseca, R., Teixeira, D.M. 2015. Phytoremediation of soils contaminated with heavy metals and strategies. In: Ansari A.A., Gill S.S., Gill R., Lanza G.R., Newsmana L. (Eds). Phytorremediation: Management of Environmental Contaminants. Vol. 1, . Switzerland, Springer. pp 133-135.

Pratas, J., Prasad, M.N.V., Freitas, H., Conde, L. 2005. Plants growing in abandoned mines of Portugal are useful for biogeochemical exploration of arsenic, antimony, tungsten and mine reclamation. Journal of Geochemical Exploration. 85, 99-107.
Saffari, M., Karimian, N., Ronaghi, A., Yasrebi, J., Ghasemi-Faseei, R. 2015. Stabilization of nickel in a contaminated calcareous amended with lowcost amendment. Journal of Soil Science and Plant Nutrition. 15, 896-913.

Söderberg, K.H., Probanza, A., Jumpponen, A., Bååth, E. 2004. The microbial community in the rhizosphere determined by community-level physiological profiles (CLPP) and direct soil-and cfu-PLFA techniques. Applied Soil Ecology. 25, 125-145.

Wardle, D.A. 1992. A comparative assessment of factors which influence microbial biomass carbon and nitrogen levels in soil. Biological Reviews. 67, 321-358. 